\title{
Pendampingan Siswa SMKN 02 Bengkulu Tengah dalam Upaya Pemanfaatan Media Penyimpanan Berbasis Cloud
}

\section{Dewi Suranti*1, Yupianti², Syisva Nurwita3 ${ }^{3}$, Satrio Candiago ${ }^{4}$, Pardi Hardianto 5}

\author{
1,2,4,5 Infomatika, Fakultas Ilmu Komputer, Universitas Dehasen Bengkulu, Indonesia \\ ${ }^{3}$ Pendidikan Guru Pendidikan Anak Usia Dini, Fakultas Keguruan dan Ilmu Pendidikan, Universitas \\ Dehasen Bengkulu, Indonesia \\ *e-mail: dewisuranti@unived.ac.id ${ }^{1}{ }_{\text {_yupiantiprana@gmail.com }}^{2}{ }_{\text {_syisvawita@gmail.com }}^{3}$
}

\begin{abstract}
Abstrak
Perkembangan teknologi ini membuat semua aktifitas yang dilakukan lebih cepat, mudah dan semua informasi yang yang tersebar sangat berlimpah yang dengan sangat mudah dapat kita akses. Salah satu pemanfaatan perkembangan yang dapat mempermudah pekerjaan teknologi yang sedang berkembang saat ini adalah cloud computing. Data yang disimpan pada cloud storage akan dapat diakses dimana saja serta kapanpun. Namun berdasarkan hasil observasi dan wawancara yang dilakukan ke mita pengabdian diperoleh informasi bahwa sebagian siswa belum memahami penggunaan, pengoperasian media penyimpanan berbasis online dalam kehidupan. Kegiatan pengabdian dilakukan dengan metode ceramah, pendampingan dan praktik langsung yang bertujuan untuk memberikan Knowledge kepada peserta didik dalam pemanfaatan media penyimpanan berbasis cloud yang sangat bermanfaat guna meningkatkan pengetahuan, pemahaman dalam pemanfaatan media penyimpanan berbasis cloud yang berguna di dalam dunia pendidikan dan kehidupan sehari-hari. Pelaksanaan kegiatan berlangsung dengan baik dan lancar serta kegiatan pengabdian ini dapat berjalan sesuai dengan rencana kegiatan. Hasil kegiatan ini memberikan banyak manfaat bagi siswa-siswi SMKN 02 Bengkulu Tengah dalam upaya pemanfaatan media penyimpanan berbasis cloud. Berdasarkan hasil evaluasi disimpulkan bahwa peserta kegiatan sangat tertarik mengikuti pendampingan guna menambah wawasan tentang media penyimpanan berbasis cloud yang sangat dibutuhkan di dalam era revolusi industri.
\end{abstract}

Kata kunci: Pendampingan, Penyimpanan, Pemanfaatan

\begin{abstract}
The development of this technology makes all activities carried out faster, easier and all the information that is spread is very abundant which we can access very easily. One of the uses of developments that can facilitate the work of technology that is currently developing is cloud computing. Data stored in cloud storage will be accessible anywhere and anytime. However, based on the results of observations and interviews conducted to service partners, information was obtained that some students did not understand the use, operation of online-based storage media in life. Service activities are carried out using lecture and practical methods that aim to provide knowledge to students in the use of cloud-based storage media which is very useful for increasing knowledge, understanding in the use of cloud-based storage media that is useful in the world of education and everyday life. The implementation of the activity went well and smoothly and this service activity could run according to the activity plan. The results of this activity provide many benefits for students of SMK N 02 Bengkulu Tengah in an effort to utilize cloud-based storage media. Based on the results of the evaluation, it was concluded that the activity participants were very interested in participating in mentoring in order to add insight into cloud-based storage media which is very much needed in the era of industrial revaluation.
\end{abstract}

Keywords: Accompaniment, Cloud Storage, Utilization

\section{PENDAHULUAN}

Dalam waktu yang singkat teknologi telah berkembang dengan sangat pesat, Hal ini terlihat dengan tersedianya bermacam-macam aplikasi yang sangat menunjang dalam kegiatan sehari-hari baik dalam bidang bisnis maupun dunia pendidikan. Perkembangan teknologi ini membuat semua aktifitas yang dilakukan lebih cepat, mudah dan semua informasi yang yang tersebar sangat berlimpah yang sangat dengan mudah dapat kita akses. (Nuril'Abidah, Hamdani, 
\& Amrozi , 2020). Hal ini sengaja dibuat untuk pendukung utama bagi kegiatan manusia, sehingga kegiatan dapat dilaksanakan dengan lebih efisien dalam waktu yang lebih cepat. (Ranggadara \& Suhendra, 2021).

Salah satu pemanfaatan perkembangan yang dapat mempermudah pekerjaan teknologi yang sedang berkembang saat ini adalah cloud computing. Cloud computing merupakan komputasi yang didukung oleh layanan jaringan komputer, skala komputasinya dapat diubah secara dinamis dan sumber dayanya disediakan melalui internet dalam bentuk jasa (Ginting, 2018,). Perkembangan teknologi informasi dan komunikasi (TIK) telah memberikan pengaruh terhadap dunia pendidikan khususnya dalam proses pembelajaran. Dukungan cloud computing atau cloud storage (Ismawan, Irfansyah, \& Apriyani, 2018) dapat memberikan kemudahan dalam proses kegiatan pembelajaran di sekolah. Pendidikan menjadi indikator pembangunan sumber daya manusia dalam sebuah bangsa. Oleh karena itu, kualitas manusia sebagai warga negara suatu bangsa sangat bergantung pada kualitas pendidikan (Karim, 2020). Cloud storage memiliki banyak keuntungan dibandingkan dengan penyimpanan data secara tradisional. Data yang disimpan pada cloud storage akan dapat diakses dimana saja serta kapanpun (Santiko, Rosidi, \& Wibawa, 2017).

Cloud salah satu layanan penyimpanan yang banyak digunakan (Aryani, Malabay, Ariessanti, \& Putra, 2020) terutama di dalam lingkungan pendidikan. Namun permasalahan yang dihadapi adalah kurangnya pengetahuan dan pemahaman peserta didik mengenai pengoperasian aplikasi cloud. Penggunaan cloud computing sebagai media penyimpanan data yang tentunya dapat memberikan keuntungan dalam menyimpan data-data penting, yang dapat diakses dimanapun dan kapanpun jika dibutuhkan dengan keamanan yang sangat terjaga kualitasnya (Dhika, Akhirina, Mustari, \& Destiawati, 2019).

Berdasarkan hasil observasi dan wawancara yang dilakukan kepada wakil kepala sekolah bidang kurikulum di Sekolah Menengah Kejuruan (SMK) Negeri 2 Bengkulu Tengah. Bahwa diperoleh informasi sebagian siswa belum memahami penggunaan, pengoperasian media penyimpanan berbasis online dalam kehidupan, yang mereka pahami bahwa media penyimpanan hanya berupa benda terlihat salah satunya flashdisk, Hardisk dan CD R. Sehingga dengan permasalahan ini pihak sekolah mengharapkan adanya kegiatan yang dapat memberikan pendampingan kepada siswa SMK N 02 Bengkulu Tengah dalam pemanfaatan media penyimpanan berbasis online (cloud). Dengan adanya pendampingan ini diharapkan dapat memberikan Knowledge kepada peserta didik dalam mengoperasaian, penggunaan dan pemanfaatan media penyimpanan dalam kehidupan yang sangat bermanfaat bagi siswa dalam mendukung pembelajaran.

Tujuan dari pelaksanaan pengabdian ini memberikan Knowledge kepada peserta didik dalam pemanfaatan media penyimpanan berbasis cloud. Sehingga sangat bermanfaat guna meningkatkan pengetahuan, pemahaman dalam pemanfaatan media penyimpanan berbasis cloud yang dapat mendukung dalam dunia pembelajaran serta dalam kehidupan sehari-hari.

\section{METODE}

Secara garis besar kerangka kegiatan pelaksanaan pengabdian ini terdiri dari beberapa tahap yang akan dilakukan disajikan pada Gambar 1.

Pelaksanaan kegiatan pengabdian untuk mengatasi permasalahan yang dihadapi dan telah disepakati dengan pihak mitra, ditetapkan rincian tahapan kegiatan sebagai berikut :

1. Tahapan Analisis Observasi

Melakukan pendekatan kepada kepala sekolah SMK N 02 Bengkulu Tengah untuk mensinergikan kegiatan-kegiatan yang akan dilakukan dalam program sekolah khususnya yang berkaitan dengan permasalahan untuk meningkatkan pemanfaatan media penyimpanan. Solusi yang ditawarkan adalah melalui pendampingan yang dapat meningkatkan pengetahuan bagi siswa sehingga dapat menjadi bekal dalam menghadapi era revolusi. 
2. Tahapan Persiapan

Tahapan persiapan meliputi persiapan peserta, tempat pelaksanaan kegiatan yaitu ruang Laboratorium Komputer SMK N 02 Bengkulu Tengah dan penyusunan materi kegiatan serta kelengkapan kegiatan yang akan dilaksanakan. Peserta kegiatan adalah siswa-siswi kelas XI SMK N 02 Bengkulu Tengah.

3. Tahapan Pelaksanaan

Tahapan pelaksanaan kegiatan dilaksanakan pada bulan Oktober 2021 dengan metode ceramah dan praktik langsung. Pelaksanaan kegiatan dilakukan oleh 2 orang dosen Fakultas Ilmu Komputer, 1 orang dosen Fakultas Ilmu Kependidikan dan Keguruan dan 2 Orang Mahasiswa Fakultas Ilmu Komputer. Kegiatan Pendampingan teknis dilakukan dengan cara periodik yang dapat memantau pelaksanaan kegiatan.

4. Tahapan Evaluasi.

Tahap akhir dari pelaksanaan kegiatan pengabdian, dengan melakukan evaluasi kegiatan guna mengetahui tingkat pemahaman siswa dalam memperoleh pengetahuan setelah kegiatan pengabdian. Dengan dilakukan evaluasi maka dapat mengukur keberhasilan dari kegiatan pendampingan. Evaluasi dilakukan dengan memberikan beberapa quis kepada peserta dengan menggunakan aplikasi Khaoot.id. Di dalam setiap evaluasi yang dilakukan yaitu pre dan post test dengan memberikan 10 pertanyaan. Kegiatan ini dinyatakan berhasil jika lebih dari 75 persen peserta kegiatan dapat menyelesaikan test tersebut. Dengan tahapan ini tim dapat mengetahui evaluasi yang akan diperbaiki pada kegiatan pengabdian selanjutnya.

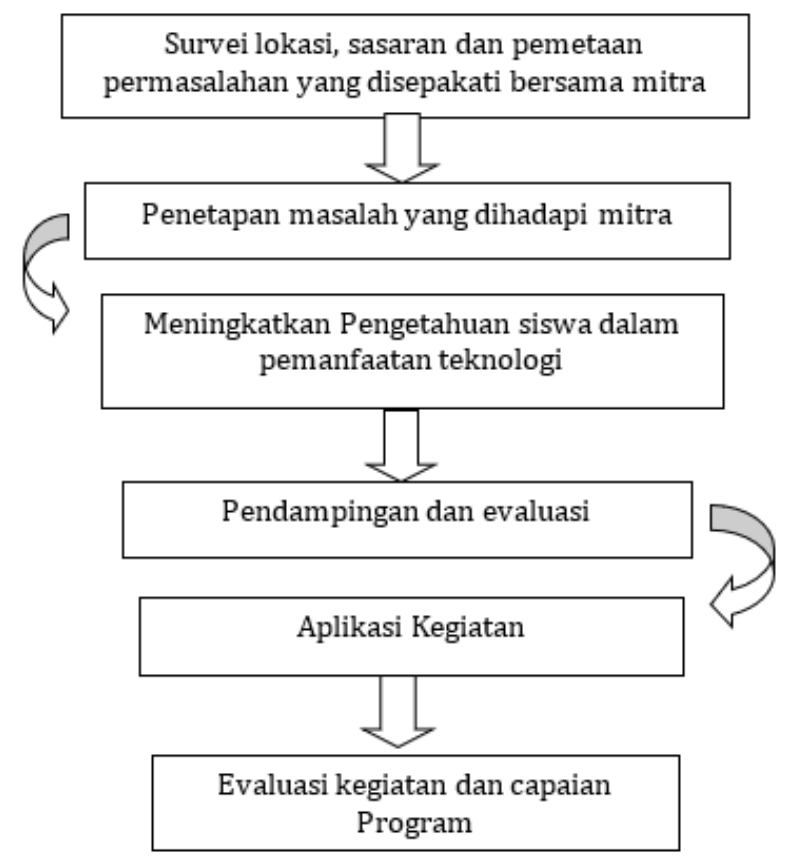

Gambar 1. Kerangka Kegiatan Program Kemitraan Masyarakat

\section{HASIL DAN PEMBAHASAN}

\subsection{Tahap Observasi}

Pelaksanaan kegiatan Pkm dimulai dengan melakukan pendekatan serta koordinasi dengan pihak mitra. Koordinasi dari pihak mitra di wakilkan oleh wakil kepala sekolah bidang kurikulum dan dari Univeritas Dehasen Bengkulu di wakilkan oleh salah satu tim kegiatan pengabdian. Berdasarkan pendekatan ini maka diperoleh informasi bahwa sebagian siswa SMK N 02 Bengkulu Tengah belum memahami penggunaan, pengoperasian media penyimpanan berbasis online dalam kehidupan, yang mereka pahami bahwa media penyimpanan hanya 
berupa benda terlihat salah satunya flasdisk, Hardisk dan CD R. Sehingga dengan permasalahan ini pihak sekolah mengharapkan adanya kegiatan yang dapat memberikan pendampingan kepada siswa SMK N 02 Bengkulu Tengah dalam pemanfaatan media penyimpanan berbasis online (cloud). Dengan adanya pendampingan ini diharapkan dapat memberikan Knowledge kepada peserta didik dalam mengoperasaian, penggunaan dan pemanfaatan media penyimpanan dalam kehidupan yang sangat bermanfaat bagi siswa dalam mendukung pembelajaran.

\subsection{Tahap Persiapan}

Berdasarkan hasil koordinasi Universitas Dehasen Bengkulu membentuk tim pengabdian yang terdiri dari 3 orang dosen yaitu 2 orang dosen Fakultas Ilmu Komputer dan 1 orang dosen Fakultas Ilmu Kependidikan dan Keguruan dan 2 orang mahasiswa. Susunan tim pelaksana Pkm dapat dilihat pada Tabel 1.

Tabel 1. Tim Pelaksana Pengabdian

\begin{tabular}{clccc}
\hline No & \multicolumn{1}{c}{ Nama } & NIDN/NPM & $\begin{array}{c}\text { Peran dalam } \\
\text { tim }\end{array}$ & Program Studi \\
\hline 1 & Dewi Suranti, M. Kom & 0222108201 & Ketua tim & Informatika \\
2 & Yupianti, M. Kom & 0203048602 & Anggota & Informatika \\
3 & Syisva Nurwita, M.Pd & 0215018901 & Anggota & PGPAUD \\
4 & Satrio Candiago & 17010155 & Anggota & Informatika \\
5 & Pardi Hardianto & 17010152 & Anggota & Informatika \\
\hline
\end{tabular}

Setelah tim terbentuk kegiatan selanjutnya adalah melakukan rapat guna penyamaan persepsi tentang materi yang akan disampaikan dalam kegiatan pendampingan. Dari kegiatan ini maka diperoleh beberapa kesepakatan diantaranya : 1). Materi kegiatan pengabdian; 2). Susunan tugas untuk setiap tim pengabdian; 3). Waktu akan dilaksanakan kegiatan; 4). Susunan acara kegiatan pengabdian.

\subsection{Tahap Pelaksanaan}

Kegiatan pendampingan dilaksanakan secara luring yang dilaksanakan pada tanggal 07 09 Oktober 2021 dari pukul 08.30 - 13.00 WIB. Terdapat beberapa kegiatan yang dilakukan selama pendampingan berlangsung agar dapat berjalan dengan baik dan terencana. Berikut ini rincian kegiatan seperti pada Tabel 2.

Tabel 2. Susunan Acara Pengabdian

\begin{tabular}{clcl}
\hline No & \multicolumn{1}{c}{ Susunan Acara } & Pukul & \multicolumn{1}{c}{ PJ } \\
\hline 1 & Pembukaan & $08.30-09.00$ & Panitia \\
2 & Coffe break & $09.00-09.15$ & Panitia \\
3 & Materi Pengenalan Media Penyimpanan & $09.15-10.30$ & Tim pengabdian \\
& Berbasis Cloud & & \\
4 & Materi Quis (Khaoot.id) & $10.30-11.00$ & Tim pengabdian \\
5 & Pendampingan dan Praktik & $11.00-12.00$ & Tim pengabdian \\
& pengoperasian Media Penyimpanan & & \\
& Berbasis Cloud & & \\
6 & Penutup & $12.00-13.00$ & Panitia \\
\hline
\end{tabular}

Materi kegiatan pendampingan yang disampaikan merujuk kepada materi penyimpanan berbasis cloud yang bermanfaat bagi peserta dalam dunia pendidikan. Penyampaian materi dilakukan dalam bentuk ceramah dengan cara melakukan presentasi menggunakan LCD Projector dan dilanjutkan dengan Tanya jawab. Penyampaian materi lebih difokuskan memberikan gambaran dari media penyimpanan berbasis cloud yang dapat digunakan bagi seorang pelajar serta pengoperasaian secara langsung, dapat dilihat pada Gambar 2. 

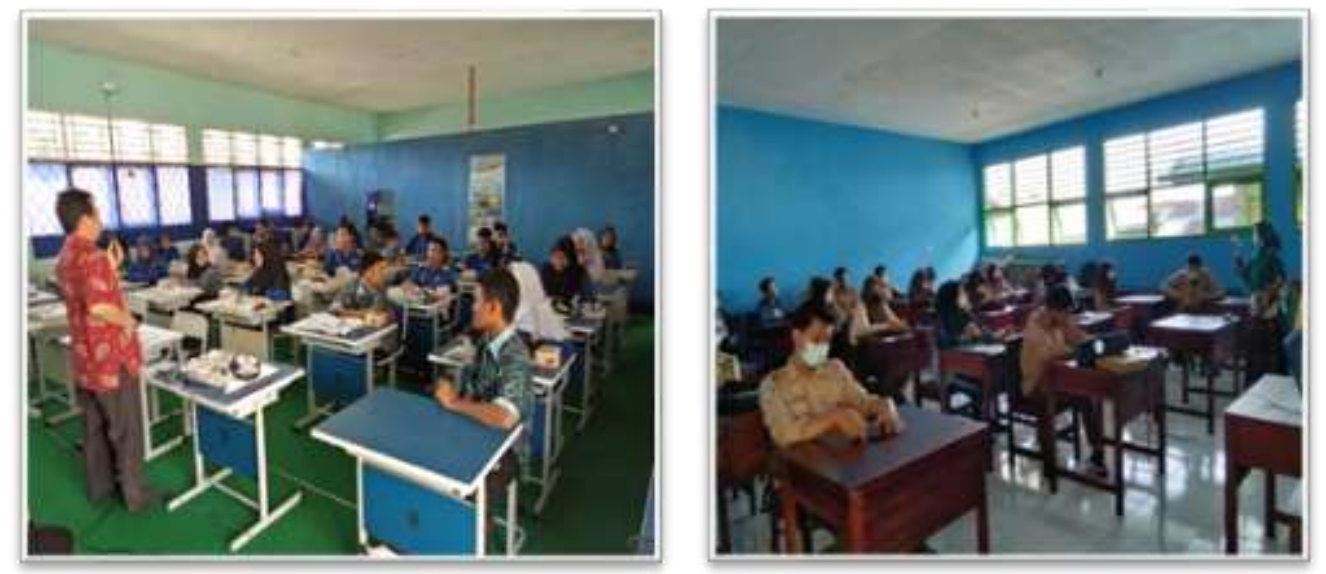

Gambar 2 . Kegiatan Pengabdian

\subsection{Tahap Evaluasi}

Setelah pelaksanaan materi toeri pengenalan media penyimpanan, praktik dan quis kegiatan ini berlangsung selama 3 hari. Hasil kegiatan pendampingan ini diukur dengan pre dan post test untuk mengetahui keberhasilan dari kegiatan dan mengetahui peningkatan pengetahuan yang diperoleh peserta. Kegiatan pengukuran ini menggunakan aplikasi Kahoot.id. Di dalam setiap evaluasi yang dilakukan yaitu pre dan post test dengan memberikan 10 pertanyaan. Kegiatan ini dinyatakan berhasil jika lebih dari 75 persen peserta kegiatan dapat menyelesaikan test tersebut. Dengan tahapan ini tim dapat mengetahui evaluasi yang akan diperbaiki pada kegiatan pengabdian selanjutnya. Khaoot dapat memberikan tampilan hasil yang diperoleh dari setiap evaluasi dapat dilihat pada Gambar 3.
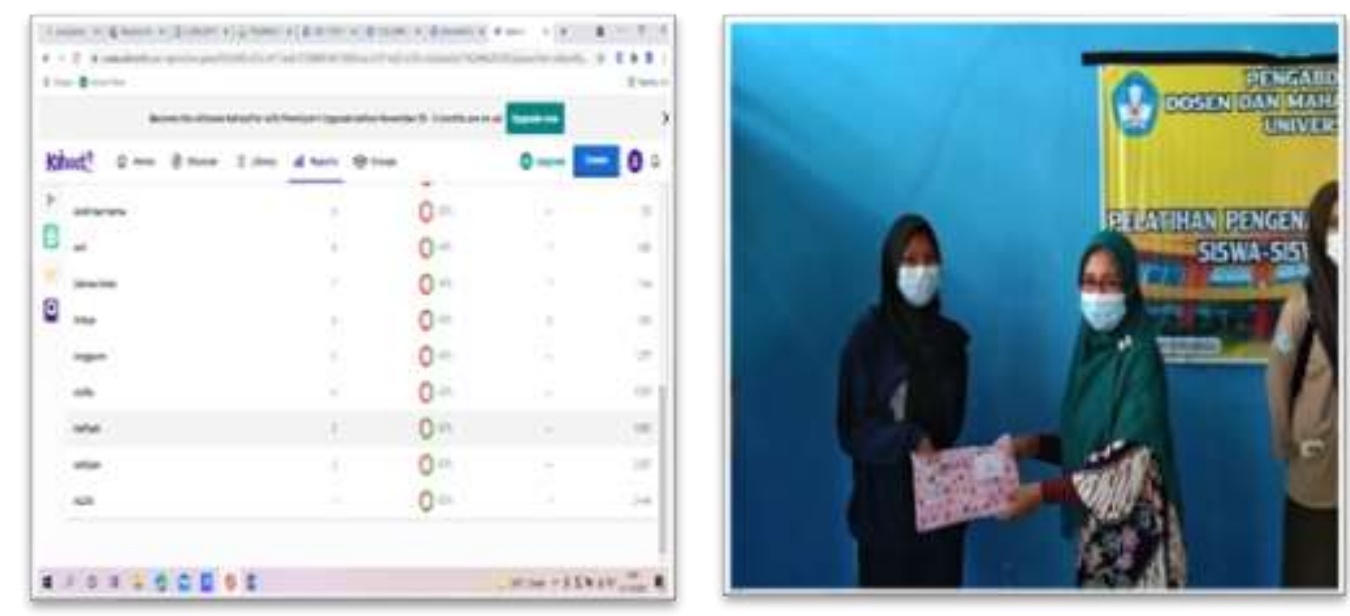

Gambar 3. Pemberian Doorprize pada Peserta Kegiatan yang Mendapatkan Nilai Tertinggi

Berdasarkan evaluasi yang telah dilakukan maka dapat disimpulkan bahwa kegiatan pendampingan siswa dalam upaya pemanfaatan media penyimpanan berbasis Cloud memberikan hasil yang sangat memuaskan. Dengan pengetahuan ini dapat memberikan ilmu dan pemahaman kepada siswa SMK N 02 Bengkulu Tengah bahwa media penyimpanan berbasis cloud di era revolusi saat ini sangat diperlukan dalam kehidupan sehari hari. Media ini dapat diakses kapanpun dan dimanapun kita membutuhkan. Peserta pendampingan merasa sangat terbantu dengan adanya pengabdian ini sehingga pandangan mereka bertambah tentang pemanfaatan teknologi. Dari kegiatan pendampingan ini sangat bermanfaat dan memiliki dampak yang sangat bagi mitra dengan meningkatnya pengetahuan siswa dalam pemanfaatan media penyimpanan berbasis cloud. 


\subsection{Tahap selanjutnya}

Tahap selanjutnya tim pengabdian akan mengadakan kegiatan selanjutnya antara lain : 1). Mengadakan pelatihan dan pendampingan dengan mengoptimal penggunaan media penyimpanan yang dapat digunakan dalam proses pembelajaran dan dapat diakses dengan gratis; 2). Memberikan pendampingan kepada guru dan orang tua dalam pemanfaatan teknologi yang dapat memberikan pengetahuan lebih mendalam.

\section{KESIMPULAN}

Berdasarkan kegiatan pengabdian kepada masyarakat yang telah dilaksanakan, dapat disimpulkan bahwa pelaksanaan kegiatan berlangsung dengan baik dan lancar serta peran peserta sangat tinggi serta kegiatan pengabdian ini dapat berjalan sesuai dengan rencana kegiatan. Hasil kegiatan ini memberikan banyak manfaat bagi siswa-siswi SMK N 02 Bengkulu Tengah dalam upaya pemanfaatan media penyimpanan berbasis cloud dan berdasarkan hasil evaluasi kegiatan pengabdian dapat disimpulkan bahwa peserta kegiatan sangat tertarik untuk mengikuti pendampingan guna menambah wawasan tentang media penyimpanan berbasis cloud yang sangat dibutuhkan di dalam era revolusi industri. Dari kegiatan pendampingan ini sangat bermanfaat dan memiliki dampak yang sangat bagi mitra dengan meningkatnya pengetahuan siswa dalam pemanfaatan media penyimpanan berbasis cloud.

\section{UCAPAN TERIMA KASIH}

Tim ucapkan terimakasih kepada Lembaga Penelitian dan Pengabdian Masyarakat Universitas Dehasen Bengkulu dan Sekolah Menengah Kejuruan (SMK) Negeri 02 Bengkulu Tengah yang telah mendukung dan memfasilitasi kegiatan pengabdian ini.

\section{DAFTAR PUSTAKA}

Aryani, D., Malabay, Ariessanti, H. D., \& Putra, S. D. (2020). Pelatihan Pemanfaatan Google Classroom untuk Mendukung Kegiatan Pembelajaran Daring saat Pandemi COVID-19 di SMPIT Insan Rabbani. Jurnal Abdidas Vol. 1 No. 5 p-ISSN 2721-9224 e-ISSN 2721-9216, 373 378.

Dhika, H., Akhirina, T., Mustari, D., \& Destiawati, F. (2019). Pemanfaatan Teknologi Cloud Computing Sebagai Media Penyimpanan Data. Jurnal PKM: Pengabdian kepada Masyarakat Vol. 02 No. 03, e-ISSN 2615-4749., 221-226.

Ginting, M. (2018,). Pemanfaatan cloud computing pada aplikasi e-learning. Jurnal Teknik Informatika Unika St. Thomas (JTIUST), Vol. 03, No. 01, 40-44.

Ismawan, F., Irfansyah, P., \& Apriyani, D. D. (2018). Pengoptimalan Cloud Storage Google Drive sebagai Media Pembelajaran untuk Guru SMP dan SMA. Jurnal PKM: Pengabdian kepada Masyarakat Vol. 01 No. 01, 61-70.

Karim, B. A. (2020). Pendidikan Perguruan Tinggi Era 4.0 Dalam Pandemi Covid-19 (Refleksi Sosiologis). Education and Learning Journal Vol. 1, No. 2, E-ISSN 2720-9156 xxX, pp. 102-112.

Nuril'Abidah, I., Hamdani, M. A., \& Amrozi , Y. (2020). Implementasi Sistem Basis Data Cloud Computing pada Sektor Pendidikan. Jurnal Sains dan Teknologi, Vol.1 No. 2, 77- 84.

Ranggadara, I., \& Suhendra. (2021). Pelatihan Pengelolaan Pembelajaran Online Berbasis Cloud Untuk Guru SMP 206 Jakarta Barat Menggunakan Google Classroom. JURNAL PASOPATI 'Pengabdian Masyarakat dan Inovasi Pengembangan Teknologi' Vol. 3, No. 1, 32-34.

Santiko, I., Rosidi, R., \& Wibawa, S. A. (2017). Pemanfaatan Private Cloud Storage Sebagai Media Penyimpanan Data E-Learning Pada Lembaga Pendidikan. JURNAL TEKNIK INFORMATIKA Vol. 10 No. 2, p-ISSN 1979-9160 / e-ISSN 2549-7901, 137-146. 